\title{
Study on the Selection of Industrial Pillar Industry in Inner Mongolia under the Restriction of Resources and Environment
}

\author{
Si Rijimoleng \\ Department of Economics \\ Central University of Finance and Economics \\ Beijing, China \\ Sa Rula \\ Department of Finance \\ Inner Mongolia University of Finance and Economics \\ Inner Mongolia, China
}

\begin{abstract}
Inner Mongolia as China's largest grassland pastoral areas, there is the most important issue to be solved that it has to develop local characteristics pillar industries and promote the development of productive forces. Economic development in Inner Mongolia is not balanced and highly dependent on resource and environment. Because of the simple and extensive economic development way, it has long been in the low-end of industrial division, unfulfilled factor driving to innovation drive change. With the economic development of Inner Mongolia, the role of industrial industry in economic growth is gradually highlighted. The industrial industry plays a main force role in Inner Mongolia. At the same time, energy consumption and environmental pollution levels also increased. It is a main concern that how to develop the pillar industry under the restriction of resources and environment and keep the sustainable development of the economy in Inner Mongolia. How to choose the industrial pillar industry is a practical significance to the continuous growth of Inner Mongolia economy. This paper use factor analysis method to select oil and gas extraction industry, gas production and supply industry, ferrous metal mining industry, automobile manufacturing industry and metal products industry as the industrial pillar industries in Inner Mongolia.
\end{abstract}

Keywords: industrial industry; pillar industry; factor analysis method

\section{Introduction}

In terms of the concept and characteristics of pillar industries, different researchers have different views and each has its own rationality. The research of pillar industry in China is accompanied by the development of foreign leading industry research theory. Foreign scholars mainly study the role of leading industry in economic growth. There is lots of leading industry selection index. Such as The Hirschman benchmark, proposed by American economist Albert Otto Hirschman in the "economic development strategy". And the Japanese economist put forward the industry benchmark and so on. Since the late 1980s, Chinese scholars have started to study the pillar industry by studying foreign industrial theories and policies. Pillar industry and leading industry have certain connection and distinction. Some leading industries have developed to a certain extent to become a pillar industry, but the pillar industry is not always the leading industry. Some industries are both pillar industries and leading industries. In the early stage of industrial development, there are pillar industries and leading industries in industrial clusters. The key to leading industries different from pillar industries is "sustained high growth rate" and emphasizes the contribution of technological progress to sustained high growth. Technological progress always plays a driving role in the development of the leading industry, and the technology always keeps the high growth rate. However, in the early stage of development, the pillar industry maintained a high growth rate, and in the later period of development, the growth rate gradually decreased. Because of the complex relationship between pillar industry and leading industry, the concept and characteristics of pillar industry and leading industry have not been. Defined .In terms of pillar industry and leading industry concept, Maxiaoyan (2005) believed that the pillar industry refers to the main body of the industrial system of a country or region within a certain period. It has a broad market prospect, high technology density, strong industrial correlation, large scale of development and good economic benefit, which will support the whole national economy. 
Wang jiaxin (1995) believes that pillar industry refers to the industry with the largest proportion of GDP and stable and extensive resources and product market. The leading industry refers to the higher income elasticity of demand in the longer term, and has strong correlation with other industries, and has higher labor productivity. Liu Weihui (2010) think, such as pillar industry refers to the industry have a significant impact with national or regional economic development, financial income, employment and technological progress, etc. in terms of production scale, speed of development and technological conditions. The industry that holds the pivotal position in current and future gross national product and industrial production.

In terms of pillar industry and leading industry characteristics, Huang xinjian et al. (2015) pointed out in the "research on pillar industry cultivation and development" that the main characteristics of leading industries are high efficiency, high growth capacity and "diffusion effect". The "diffusion effect" feature is consistent with that of Ma xiaoyan et al. (2005).However, the main characteristics of pillar industries are: more proportion, more output, more employment, more income. According to Sun ruijie (2004), the characteristics of pillar industries are: it has large proportion in GDP, large correlation effect, high technology content, large market demand and sustainable development. Ma xiaoyan (2005) pointed out that the pillar industry features include high technology intensity, strong market expansion ability, high correlation degree, large economic scale and significant economic benefit. They also think, such as high employment, save resources, comparative advantage and sustainable development cannot be said to the characteristics of the pillar industries. They are only the advantages and limitations of the selection of pillar industries.

Based on the above literature research, in such aspects as the concept and characters of the pillar industries, it is found that although many researchers have different understanding of the concept of pillar industry, they agree on those characteristics: the bigger GDP proportion, large production scale, large correlation and large market demand.

This paper agrees with Huang xinjian (2015) and Ma xiaoyan's (2005)definition of pillar industry and add the limiting factors about resource conservation and environmental friendliness to analysis industrial pillar industry in Inner Mongolia under the restriction of resources and environment.

\section{The construction of standard and index system of pillar industry in Inner Mongolia}

Because of the complex relationship between pillar industry and leading industry, the index system construction method in pillar industry selection is generally based on the construction method of leading industry index system. At the same time, the national economy pillar industry selection and regional economy pillar industry selection standard are different. National economy considers industrial structure optimization and industrial system integrity. And regional economy considers advantageous industry and characteristic economy. Regional economy should consider regional particularity when choosing pillar industries. Regional characteristic industry as the pillar industry of local economic growth.

Maohanying (2002) selected the pillar industries of the three gorges reservoir area, the water environment pollution index, air pollution index, solid waste pollution index, energy consumption index, resource consumption index, market demand condition index, market sales index, market share index, the balance sheet index, the capital tax index, value tax index, technical innovation ability index, labor placement index, forward driving coefficient, backward driving coefficient and lateral driving coefficient were selected from six levels of ecological environment, Product market, economic benefit, technological innovation ability, labor force, industry correlation to establish the pillar industry selection index system. Fang shuai et al. (2007) used seven indicators to construct the index system of pillar industries and make factor analysis to select the reasonable pillar industry. The seven indicators are demand income elasticity, industrial correlation degree, contribution rate of national economy, output value, employment scale, industrial added value rate, total labor productivity respectively. Wang keyi et al. (2008) selected eight indicators, such as the contribution rate of industrial output and the elasticity of demand income, induction coefficient, influence coefficient, comparative labor productivity coefficient, comparative advantage tax rate coefficient, technical progress contribution and comprehensive employment coefficient from the five levels of the industry market scale benchmark, the industry correlation degree benchmark, the industry comparative advantage benchmark, the industry technical progress standard and the social employment benchmark, to construct the pillar industry selection index system. 
Liu weihui et al. (2010) used the same benchmark system with Wang keyi et al. (2008) to select the pillar industries of the regional modern service industry. The evaluation index system of the pillar industry is mainly based on the Rostow criterion, the Hirschman criterion, the dynamic comparative advantage criterion, etc. In addition, there are also technical progress criteria, expanded employment criteria, Labor area division of labor principle, bottleneck criterion, scale criterion, high value-added criterion and so on. Most studies have not taken into account resource and environmental factors in the selection of pillar industries. Guan aiping et al. (2002) believed that the selection of pillar industries should consider sustainability and environmental factors. Guo kesha (2003) also pointed out that industrial sustainability is reflected in low energy consumption and low pollution. But they didn't specify the measures and did the quantitative analysis. The energy and environmental indicators used in the existing literature are: carbon dioxide emission rate (zhangzhaohua et al., 2013),energy consumption, the tree wastes management rate (Chen lina et al., 2012),coal consumption per unit of output, oil fuel consumption per unit of output, industrial emissions, industrial liquid emissions, industrial solid waste production (Caixing, 2010) etc.

In this paper, based on the above pillar industry selection criteria and indicators, according to the special situation of the resource and environment in Inner Mongolia, and consider the data availability, select the following indicators as Inner Mongolia industrial pillar industry selection index system (see table 1 for details).

(1) Industry market scale benchmark. The market size determines the sustainable and stable development of a certain industry. Measures of the scale of industrial market include industrial output contribution (X1), growth contribution (X2), and demand income elasticity (X3). Its calculation formula is as follows:

$$
\begin{gathered}
\text { industrial output contribution } \\
=\frac{\text { The gross product of an industrystry gross product }}{\text { Gross industrial product }} \\
\text { growth contribution }=\frac{\text { increase in the output of an industry }}{\text { increase in the gross industrial product }}
\end{gathered}
$$

$$
\text { demand income elasticity }=\frac{\text { increase rate in demand of an industry }}{\text { increase rate in the income of industry }}
$$

(2) Comparative advantage criterion. The comparative advantage criterion is based on Ricardo's theory of comparative advantage. According to the theory of comparative advantage, a country should specialize in producing products with comparative advantages and export the product. And imports of relatively inferior products, thus reducing costs. The two trading countries also benefited from the comparative advantage. This theory can also be used in the division and development of the region. Each region according to its own resource endowment and the region characteristic, develop the comparative advantage industry in this area. The comparative labor productivity index (X4) was chosen to analyze the comparative advantage industry in the region. Its calculation formula is as follows:

$$
\text { comparative labor productivity }=\frac{\frac{\text { totoal output value of an industry }}{\text { the average anual employment of th is industry }}}{\frac{\text { total output value of each industry }}{\text { the average annual employment of each industry }}}
$$

(3) Economic benefit benchmark. In this paper use the industrial cost profit margin(X5) to calculate the economic benefit benchmark. Its calculation formula is as follows:

$$
\text { Industrial cost profit margin }=\frac{\text { Industry profits }}{\text { Industrial cost }}
$$

(4) Resource and environmental benchmarks. Most leading industries in Inner Mongolia have high dependence on natural resources. At the same time, with the development of Inner Mongolia economy, environmental pollution and other phenomena gradually appeared. Therefore, the resource and environmental baseline should be taken into account when selecting pillar industries and measured by energy consumption (X6) and "three wastes" management coefficient. In the "three wastes" governance coefficient, because of the difference in the calculation of the gas pollution control data, this paper does not consider the exhaust treatment coefficient. Then, environmental benchmarking is represented by waste water treatment coefficient (X7) and solid waste management coefficient (X8). 


$$
\begin{gathered}
\text { Energy consumption }=\frac{\text { Total energy consumption of an industry }}{\text { The total output value of an industry }} \\
\text { Wastewater treatment coefficient }=\frac{\text { the amount of wastewater treatment }}{\text { discharge amount of wastewater }} \\
\text { Solid waste management coefficient }=\frac{\text { The amount of solid waste management }}{\text { discharge amount of solid waste }}
\end{gathered}
$$

Table 1 selection index system of Inner Mongolia pillar industry

\begin{tabular}{c|l}
\hline Pillar industry selection index & \\
\hline industrial output contribution & $\mathrm{X} 1$ \\
\hline growth contribution & $\mathrm{X} 2$ \\
\hline demand income elasticity & $\mathrm{X} 3$ \\
\hline comparative labor productivity & $\mathrm{X} 4$ \\
\hline Industrial cost profit margin & $\mathrm{X} 5$ \\
\hline Energy consumption & $\mathrm{X} 6$ \\
\hline Wastewater treatment coefficient & $\mathrm{X} 7$ \\
\hline Solid waste management coefficient & $\mathrm{X} 8$
\end{tabular}

\section{The selection of industrial pillar industry in Inner Mongolia}

According to the pillar industry evaluation index system mentioned above, using factor analysis method to evaluate and analyze Inner Mongolia industrial industry, choose the reasonable pillar industry suitable for Inner Mongolia economic growth.

\subsection{Data collection and sorting}

According to the characteristics and basic situation of economic development in Inner Mongolia, as well as the availability of data, this paper selects and evaluates industries such as coal mining and washing industry (Y1),oil and gas extraction industry (Y2), ferrous metal mining industry (Y3),non-ferrous metal mining industry (Y4), nonmetallic mining industry (Y5), agricultural and sideline food processing industry (Y6),food manufacturing (Y7),oil processing (Y8),non-metallic mineral products (Y9),ferrous metal smelting and rolling processing industry (Y10),Non-ferrous metal smelting and rolling processing industry (Y11), metal products (Y12), automobile manufacturing (Y13),electricity, thermal production and supply (Y14),gas production and supply (Y15), water production and supply (Y16)etc. The data from the 2015 Inner Mongolia statistical yearbook,2015 China industrial statistics yearbook,2015 China environment yearbook, 2015 China environmental statistics yearbook and through the corresponding operation obtain the above eight index values. Where Inner Mongolia environmental pollution emissions are not available according to sector data. Therefore, this paper takes China's industrial environmental pollution index as an alternative to the environmental pollution index of Inner Mongolia industry. The raw data is shown in table 2 below. 
Table 2 index values of industrial sector

\begin{tabular}{l|l|l|l|l|l|l|l|l}
\hline & $\mathrm{X} 1$ & $\mathrm{X} 2$ & $\mathrm{X} 3$ & $\mathrm{X} 4$ & $\mathrm{X} 5$ & $\mathrm{X} 6$ & $\mathrm{X} 7$ & $\mathrm{X} 8$ \\
\hline $\mathrm{Y} 1$ & 0.382 & -26.399 & -61.596 & 4.635 & 0.192 & 222.143 & 1.336 & 0.230 \\
\hline Y2 & 0.074 & 3.235 & 47.540 & 31.170 & 0.179 & 2506.78 & 16.305 & 0.165 \\
\hline Y3 & 0.067 & 4.322 & 72.906 & 4.476 & 0.105 & 423.454 & 12.736 & 0.590 \\
\hline Y5 & 0.065 & -2.380 & -34.287 & 4.327 & 0.130 & 816.540 & 3.561 & 0.303 \\
\hline Y6 & 0.027 & -0.757 & -27.032 & 4.086 & 0.081 & 794.864 & 2.276 & 0.169 \\
\hline Y7 & 0.168 & -8.373 & -45.895 & 6.217 & 0.059 & 920.636 & 0.824 & 0.048 \\
\hline Y8 & 0.072 & 1.118 & 15.995 & 3.779 & 0.112 & 421.597 & 0.871 & 0.052 \\
\hline Y9 & 0.102 & 12.463 & 154.611 & 5.250 & -0.053 & 106.187 & 0.874 & 0.218 \\
\hline Y10 & 0.087 & -1.313 & -14.669 & 3.745 & 0.063 & 120.831 & 2.592 & 0.034 \\
\hline Y11 & 0.178 & -6.490 & -34.290 & 3.568 & 0.013 & 64.120 & 26.719 & 0.061 \\
\hline Y12 & 0.167 & -16.839 & -85.640 & 5.703 & 0.016 & 108.679 & 3.537 & 0.330 \\
\hline Y13 & 0.056 & 3.920 & 79.476 & 3.477 & 0.039 & 2131.29 & 1.743 & 0.108 \\
\hline Y14 & 0.024 & 0.513 & 21.996 & 4.890 & -0.034 & 2841.75 & 0.912 & 0.156 \\
\hline Y15 & 0.026 & 5.572 & 338.355 & 10.873 & 0.092 & 573.365 & 1.569 & 0.050 \\
\hline & 0.003 & 0.018 & 5.809 & 0.840 & -0.015 & 235.669 & 8.033 & 0.000 \\
\hline Y16 & 13.069 & 63.071 & 5.012 & 0.066 & 29.404 & 2.104 & 0.075 \\
\hline
\end{tabular}

\subsection{Comprehensive evaluation of factor analysis methods}

According to the factor analysis method and the principle of using the statistical software SPSS17, calculate the correlation coefficient matrix, variance table and factor loading matrix, etc. On this basis, calculate the comprehensive evaluation value and sort by it to get the industrial pillar industry in Inner Mongolia.

(1) correlation coefficient matrix

The correlation coefficient matrix obtained through analysis is shown in table 3 below. As shown in table 3 , there is a large correlation between indicators, which can do factor analysis. Furthermore, KMO and Bartlett tests were further conducted, and the value was found to be 0.503 , greater than 0.5.so, we can do factor analysis. 
Table 3 index correlation coefficient matrix

\begin{tabular}{|c|c|c|c|c|c|c|c|c|c|}
\hline & & $\mathrm{X} 1$ & $\mathrm{X} 2$ & X3 & $\mathrm{X} 4$ & X5 & X6 & $\mathrm{X} 7$ & X8 \\
\hline \multirow{8}{*}{$\begin{array}{l}\text { Correla- } \\
\text { tion }\end{array}$} & $\mathrm{X} 1$ & 1.000 & -.587 & -.372 & -.074 & .324 & -.385 & .009 & .071 \\
\hline & $\mathrm{X} 2$ & -.587 & 1.000 & .641 & .133 & -.303 & .153 & -.025 & -.122 \\
\hline & X3 & -.372 & .641 & 1.000 & .226 & -.083 & .072 & -.134 & -.101 \\
\hline & $\mathrm{X} 4$ & -.074 & .133 & .226 & 1.000 & .457 & .491 & .305 & .018 \\
\hline & $\mathrm{X} 5$ & .324 & -.303 & -.083 & .457 & 1.000 & .045 & .052 & .209 \\
\hline & X6 & -.385 & .153 & .072 & .491 & .045 & 1.000 & -.021 & -.029 \\
\hline & $\mathrm{X} 7$ & .009 & -.025 & -.134 & .305 & .052 & -.021 & 1.000 & .109 \\
\hline & $\mathrm{X} 8$ & .071 & -.122 & -.101 & .018 & .209 & -.029 & .109 & 1.000 \\
\hline \multirow{8}{*}{ Sig. } & $\mathrm{X} 1$ & & .008 & .078 & .393 & .110 & .071 & .487 & .397 \\
\hline & $\mathrm{X} 2$ & .008 & & .004 & .312 & .127 & .286 & .464 & .327 \\
\hline & $\mathrm{X} 3$ & .078 & .004 & & .200 & .380 & .395 & .310 & .355 \\
\hline & $\mathrm{X} 4$ & .393 & .312 & .200 & & .037 & .027 & .125 & .474 \\
\hline & $\mathrm{X} 5$ & .110 & .127 & .380 & .037 & & .434 & .424 & .218 \\
\hline & $\mathrm{X} 6$ & .071 & .286 & .395 & .027 & .434 & & .469 & .458 \\
\hline & $\mathrm{X} 7$ & .487 & .464 & .310 & .125 & .424 & .469 & & .344 \\
\hline & $\mathrm{X} 8$ & .397 & .327 & .355 & .474 & .218 & .458 & .344 & \\
\hline
\end{tabular}

a. The determinant $=.096$

(2) Calculate the eigenvalue, contribution rate and determine the common factor

In terms of determining the number of common factors, there are the eigenvalue criterion, Cattell criterion, accumulative variance contribution rate criterion and so on. When determining the number of common factors, the analysis is usually judged by multiple criteria. As shown in table 4 below, by combining multiple criteria, three common factors are selected for analysis, and their cumulative variance contribution rate is $64.8 \%$, which is representative. In order to divide the coefficient from 0 to 1 in the factor loading matrix, the initial factor loading matrix is the maximum rotation of variance. In this paper, we use the orthogonal rotation method of Kaiser standardization to carry out five rotations of the extracted common factors and obtain the total variance of the interpretation (table 4). The number of common factors is 3 .

Table 4 the total variance explained

\begin{tabular}{|c|c|c|c|c|c|c|c|c|c|}
\hline \multirow[b]{2}{*}{ index } & \multicolumn{3}{|c|}{ Initial eigenvalue } & \multicolumn{3}{|c|}{ Extract sum of squares load } & \multicolumn{3}{|c|}{$\begin{array}{l}\text { Rotational sum of squares } \\
\text { load }\end{array}$} \\
\hline & sum & $\begin{array}{l}\% \text { of the } \\
\text { variance }\end{array}$ & $\begin{array}{l}\text { Cumulat } \\
\text { ive } \%\end{array}$ & sum & $\begin{array}{l}\% \text { of the } \\
\text { variance }\end{array}$ & $\begin{array}{l}\text { Cumulat } \\
\text { ive } \%\end{array}$ & sum & $\begin{array}{l}\% \text { of the } \\
\text { variance }\end{array}$ & $\begin{array}{l}\text { Cumulat } \\
\text { ive \% }\end{array}$ \\
\hline 1 & 2.375 & 29.684 & 29.684 & 2.375 & 29.684 & 29.684 & 2.297 & 28.707 & 28.707 \\
\hline 2 & 1.789 & 22.361 & 52.044 & 1.789 & 22.361 & 52.044 & 1.714 & 21.423 & 50.129 \\
\hline 3 & 1.024 & 12.799 & 64.843 & 1.024 & 12.799 & 64.843 & 1.177 & 14.714 & 64.843 \\
\hline 4 & 0.993 & 12.409 & 77.252 & & & & & & \\
\hline 5 & 0.918 & 11.47 & 88.722 & & & & & & \\
\hline 6 & 0.41 & 5.13 & 93.852 & & & & & & \\
\hline 7 & 0.282 & 3.522 & 97.374 & & & & & & \\
\hline 8 & 0.21 & 2.626 & 100 & & & & & & \\
\hline
\end{tabular}


(3) Solving factor score and comprehensive score

variance maximization orthogonal rotation of common factor, by rotating the load matrix (as shown in table 5), obtain 3 main factors. The first main factor, $\mathrm{C} 1$, has a large load on the industrial output contribution, the growth contribution and the elasticity of demand income. The main performance is industrial production efficiency. The second main factor, C2, has a large load in comparative labor productivity, Industrial cost profit margin and energy consumption, mainly showing the comparative advantage and resource advantage of the industry. The third factor, C3, has a large load on wastewater treatment coefficient and solid waste management coefficient, mainly showing the degree of environmental pollution of the industry.

Table 5 the rotated load matrix

\begin{tabular}{c|l|l|l}
\hline & Main factors & \multicolumn{2}{l}{} \\
\hline & 1 & 2 & 3 \\
\hline industrial output contribution & 0.859 & -0.104 & 0.124 \\
\hline growth contribution & -0.801 & 0.054 & -0.186 \\
\hline demand income elasticity & 0.731 & 0.011 & -0.152 \\
\hline comparative labor productivity & 0.267 & 0.878 & -0.082 \\
\hline Industrial cost profit margin & -0.357 & 0.701 & -0.33 \\
\hline Energy consumption & 0.447 & 0.523 & -0.201 \\
\hline Wastewater treatment coefficient & -0.073 & 0.412 & 0.803 \\
\hline Solid waste management coefficient & -0.238 & 0.263 & 0.388 \\
\hline
\end{tabular}

The contribution rate of variance of each factor accounted for the proportion of the total variance contribution of the three factors as the weight, and weighted summary the three-main factor $\mathrm{C} 1, \mathrm{C} 2, \mathrm{C} 3$ scores and comprehensive score $\mathrm{C}$ of the development level of the 16 industrial sectors in 2014(see table 6).

Table 6 factor scores and ranking results of the development level of 16 industrial sectors

\begin{tabular}{|c|c|c|c|c|}
\hline Industrial sectors & $\mathrm{C} 1$ & $\mathrm{C} 2$ & $\mathrm{C} 3$ & $\mathrm{C}$ \\
\hline oil and gas extraction industry(Y2) & 0.397 & 3.103 & 1.234 & 1.481 \\
\hline gas production and supply (Y15) & 1.215 & 0.787 & -1.132 & 0.541 \\
\hline ferrous metal mining industry (Y3) & 0.317 & -0.144 & 1.925 & 0.530 \\
\hline automobile manufacturing (Y13) & 0.890 & 0.130 & -0.480 & 0.328 \\
\hline metal products (Y12) & 0.707 & 0.261 & -0.711 & 0.238 \\
\hline oil processing (Y8) & 1.148 & -0.952 & -0.274 & 0.132 \\
\hline $\begin{array}{l}\text { ferrous metal smelting and rolling processing } \\
\text { industry (Y10) }\end{array}$ & -0.163 & -1.079 & 2.227 & 0.077 \\
\hline non-ferrous metal mining industry (Y4) & -0.357 & 0.194 & 0.206 & -0.047 \\
\hline non-metallic mining industry (Y5) & 0.055 & -0.115 & -0.199 & -0.059 \\
\hline water production and supply (Y16) & 0.674 & -1.191 & 0.103 & -0.072 \\
\hline food manufacturing (Y7) & -0.095 & -0.006 & -0.811 & -0.228 \\
\hline electricity, thermal production and supply (Y14) & 0.041 & -0.318 & -0.685 & -0.242 \\
\hline non-metallic mineral products (Y9) & -0.141 & -0.482 & -0.528 & -0.342 \\
\hline $\begin{array}{l}\text { agricultural and sideline food processing } \\
\text { industry (Y6) }\end{array}$ & -0.719 & 0.019 & -0.770 & -0.486 \\
\hline $\begin{array}{l}\text { Non-ferrous metal smelting and rolling } \\
\text { processing industry (Y11) }\end{array}$ & -1.083 & -0.717 & 0.504 & -0.602 \\
\hline coal mining and washing industry (Y1) & -2.885 & 0.509 & -0.612 & -1.248 \\
\hline
\end{tabular}

Note: $\mathrm{C}=28.707 / 64.843 \mathrm{C} 1+21.423 / 64.843 \mathrm{C} 2+14.714 / 64.843 \mathrm{C} 3$. The industry in the table is ranked in descending order of comprehensive scores. 


\section{(4) Factor analysis conclusion}

Comprehensive scores of various industries, we can see that the industry with the best development level and the core driving force for Inner Mongolia's economy is oil and gas exploration industry, gas production and supply, and ferrous metal mining industry. According to the nature of the industry, all three industries belong to the mining and processing industry, which also reflects the rich mineral resources in Inner Mongolia. Inner Mongolia can promote economic growth in a reasonable and efficient way depending on its unique natural endowment. In combination with the actual situation of Inner Mongolia, the oil and gas extraction industry's ranking is due to the influence of natural gas extraction industry in ordos city, Inner Mongolia. Ferrous metal mining industry is a booming industry in Baotou city, Inner Mongolia. By dividing the scores of the main factors, it is found that the three industries become the pillar industries in Inner Mongolia for different reasons. Gas production and supply industry become the pillar industry is because of the main factor of industrial production efficiency is higher. It shows that in many industries, the industry has high production efficiency and production level. Oil and gas exploration industry become the pillar industry is because of the main factor of comparative advantage of industry was higher.

It shows that Inner Mongolia has a comparative advantage in oil and gas exploitation. Ferrous metal mining is an advantage in environmental pollution degree, which indicates that the industry is focusing on treating wastewater, waste residue and other environmental management.

From the point of view of factor scores, automobile manufacturing and metal products are ranked fourth and fifth respectively. From the nature of the industry, both industries are heavy industry. This conclusion is also consistent with the actual situation in Inner Mongolia. The automobile manufacturing and metal products industry is the heavy industry in Baotou, Inner Mongolia. The score is high because the main factor score of industrial production efficiency is higher, which indicates that the industry has higher production efficiency and production level. In June 2016, Inner Mongolia Baotou city bureau of statistics released the report pointed that the growth rate of automobile manufacturing, ferrous metal smelting and rolling processing industry and metal products industry is higher than that of average level of whole city in Baotou. The growth rate was $38.4 \%, 9.1 \%$ and $7.9 \%$ respectively. Therefore, we can consider these five industries as the pillar industries in Inner Mongolia.

It needs to be pointed out that the industry with a high contribution rate of industrial production is not necessarily the factor scores are high, which also confirms that the large quantity of production does not mean high quality. This is shown in table 7. Such as, coal mining and washing industry accounted for the first place in the industry output contribution rate in 16 industries, and the factor comprehensive score was the lowest. It shows that the industry has provided a great contribution to the economic growth of Inner Mongolia, but it is relatively backward in both production efficiency and environmental governance. The production efficiency and production level of the industry are low, and the development model of low efficiency, high energy consumption and high pollution can hardly keep the sustained economic growth of Inner Mongolia. Without governance and change, although Inner Mongolia has relatively large output and higher industry contribution rate in this industry, it is difficult to realize long-term development for pillar industry. The electricity, thermal production and supply industry, as well as Non-ferrous metal smelting and rolling processing industry are similar to coal mining and washing industry. 
Table 7 comparison of factor scores and contribution rate of output of each industry

\begin{tabular}{l|l|l|l|l}
\hline industry & $\begin{array}{l}\text { contribution } \\
\text { rate of output }\end{array}$ & rank & factor scores & rank \\
\hline oil and gas extraction industry & 0.074 & 8 & 1.481 & 1 \\
\hline gas production and supply & 0.026 & 14 & 0.541 & 2 \\
\hline coal mining and washing industry & 0.382 & 1 & -1.248 & 16 \\
\hline metal products & 0.056 & 12 & 0.238 & 5 \\
\hline non-ferrous metal mining industry & 0.065 & 11 & -0.047 & 8 \\
\hline automobile manufacturing food & 0.024 & 15 & 0.328 & 4 \\
\hline $\begin{array}{l}\text { agricultural and sideline forssing industry } \\
\text { processing }\end{array}$ & 0.168 & 4 & -0.486 & 14 \\
\hline $\begin{array}{l}\text { food manufacturing } \\
\text { non-metallic mining industry }\end{array}$ & 0.072 & 9 & -0.228 & 11 \\
\hline ferrous metal mining industry & 0.067 & 13 & -0.059 & 9 \\
\hline $\begin{array}{l}\text { electricity, thermal production and } \\
\text { supply }\end{array}$ & 0.229 & 2 & 0.530 & 3 \\
\hline non-metallic mineral products & 0.087 & 7 & -0.242 & 12 \\
\hline $\begin{array}{l}\text { Non-ferrous metal smelting and } \\
\text { rolling processing industry }\end{array}$ & 0.167 & 5 & -0.602 & 13 \\
\hline $\begin{array}{l}\text { oil processing } \\
\text { ferrous metal smelting and rolling } \\
\text { processing industry }\end{array}$ & 0.178 & 3 & 0.077 & 15 \\
\hline \begin{tabular}{l} 
water production and supply \\
\hline
\end{tabular} & 0.003 & 16 & -0.072 & 6 \\
\hline
\end{tabular}

\section{Conclusion}

Through the calculation, we get the industrial factor score and ranking. Five industries, such as oil and gas extraction industry, gas production and supply industry, ferrous metal mining industry, automobile manufacturing industry and metal products industry ranked in the top five. Combined with abundant natural resources in Inner Mongolia, and the characteristics that most of Inner Mongolia industrial industry rely on natural resources, considers the current economic development goal while balancing the long-term economic development goals to improve the deep processing capacity of the industrial industry and realize efficient utilization of resources. Combined with the feature of Inner Mongolia, focus on developing oil and gas extraction industry, gas production and supply industry, ferrous metal mining industry, automobile manufacturing industry and metal products industry. At the same time, enhance its deep processing capacity and waste disposal capacity.

\section{References}

Ma xiaoyan, luo ling. research on the construction of pillar industry theory [J]. financial science, 2005 (09), pp.134-140.

Wang jiaxin. the concept, selection and action mechanism of pillar industry [J]. Jiangsu social science, 1995 (08), pp.31-36.

Liu weihui, wang lianqiu, Chen guosheng. research on the selection of pillar industries in modern service industry based on factor analysis [J]. economic dynamics, 2010 (12) pp.84-86.

Sun ruijie, zhaoxin. the pillar industry chain of the Marine economy -- taking Qingdao as an example [J]. ocean development and management, 2008 (11), pp. 73-77.

Maohanying, Gaoqun, Fengrenguo. pillar industry selection in the ecological environment constraint of the three gorges reservoir area [J]. journal of geography, 2002(05), pp.553-560. 
Fang shuai, ji jianyue, Lin zefu. research on the selection of pillar industries of Marine economy in bohai region [J], science and technology management, 2007 (06), pp.108-111.

Wang keyi and dong sheng. the study on the selection of provincial pillar industries based on factor analysis -- a case study of liaoning province [J]. journal of Northeastern University, 2008 (05), pp.220-225.

Guan aiping, wang yu. the selection of regional leading industries [J]. statistical research, 2002 (12), pp.37-40.

Guo kesha. selection of emerging leading industries in the new era of industrialization [J]. China industrial economy, 2003 (02), pp.5-14.

Zhang zhenghua, liuhua, pendiyun. Study on the choice of leading industry of low carbon city -- taking Nanchang, Jiangxi as an example. Jiangxi social science, 2013 (02), pp.62-66.

Chen lina, zhanghua. regional leading industry selection under the background of low carbon economy -- taking sichuan province as an example. economic restructuring, 2012 (05), pp.174-177.

Caixing. the selection of leading industry in China's manufacturing industry under the background of low carbon economy [J]. systems engineering, 2010 (12), pp.105-110. 